\title{
Data Integration to Improve Real-world Health Outcomes Research for Non-Small Cell Lung Cancer in the United States: Descriptive and Qualitative Exploration
}

Michael Grabner ${ }^{1}$, PhD; Cliff Molife ${ }^{2}, \mathrm{MPH}, \mathrm{PhD}$; Liya Wang ${ }^{1}, \mathrm{PhD} ;$ Katherine B Winfree $^{2}, \mathrm{PhD}$; Zhanglin Lin Cui ${ }^{2}$, $\mathrm{PhD}$; Gebra Cuyun Carter ${ }^{2}$, PhD; Lisa M Hess ${ }^{2}, \mathrm{PhD}$

\footnotetext{
${ }^{1}$ HealthCore Inc, Wilmington, DE, United States

${ }^{2}$ Eli Lilly and Company, Indianapolis, IN, United States
}

\section{Corresponding Author:}

Michael Grabner, PhD

HealthCore Inc

123 Justison Street

Wilmington, DE, 19801

United States

Phone: 13022302000

Email: mgrabner@healthcore.com

\begin{abstract}
Background: The integration of data from disparate sources could help alleviate data insufficiency in real-world studies and compensate for the inadequacies of single data sources and short-duration, small sample size studies while improving the utility of data for research.

Objective: This study aims to describe and evaluate a process of integrating data from several complementary sources to conduct health outcomes research in patients with non-small cell lung cancer (NSCLC). The integrated data set is also used to describe patient demographics, clinical characteristics, treatment patterns, and mortality rates.

Methods: This retrospective cohort study integrated data from 4 sources: administrative claims from the HealthCore Integrated Research Database, clinical data from a Cancer Care Quality Program (CCQP), clinical data from abstracted medical records (MRs), and mortality data from the US Social Security Administration. Patients with lung cancer who initiated second-line ( $2 \mathrm{~L})$ therapy between November 01, 2015, and April 13, 2018, were identified in the claims and CCQP data. Eligible patients were 18 years or older and received atezolizumab, docetaxel, erlotinib, nivolumab, pembrolizumab, pemetrexed, or ramucirumab in the $2 \mathrm{~L}$ setting. The main analysis cohort included patients with claims data and data from at least one additional data source (CCQP or MR). Patients without integrated data (claims only) were reported separately. Descriptive and univariate statistics were reported.
\end{abstract}

Results: Data integration resulted in a main analysis cohort of 2195 patients with NSCLC; 2106 patients had CCQP and 407 patients had MR data. The claims-only cohort included 931 eligible patients. For the main analysis cohort, the mean age was 62.1 (SD 9.27) years, 48.56\% (1066/2195) were female, the median length of follow-up was 6.8 months, and for 37.77\% (829/2195), death was observed. For the claims-only cohort, the mean age was 66.6 (SD 12.69) years, 52.1\% (485/931) were female, the median length of follow-up was 8.6 months, and for $29.3 \%$ (273/931), death was observed. The most frequent $2 \mathrm{~L}$ treatment was immunotherapy (1094/2195, 49.84\%), followed by platinum-based regimens $(472 / 2195,21.50 \%)$ and single-agent chemotherapy (441/2195, 20.09\%); mean duration of 2L therapy was 5.6 (SD 4.9, median 4) months. We describe challenges and learnings from the data integration process, and the benefits of the integrated data set, which includes a richer set of clinical and outcome data to supplement the utilization metrics available in administrative claims.

Conclusions: The management of patients with NSCLC requires care from a multidisciplinary team, leading to a lack of a single aggregated data source in real-world settings. The availability of integrated clinical data from MRs, health plan claims, and other sources of clinical care may improve the ability to assess emerging treatments.

(JMIR Cancer 2021;7(2):e23161) doi: 10.2196/23161 


\section{KEYWORDS}

non-small cell lung cancer; cancer; data aggregation; real-world data; administrative claims data; medical records; electronic health record; retrospective study; population health; health services research

\section{Introduction}

\section{Background}

Real-world health outcomes research is often challenged by data insufficiency resulting from studies using a single data source and/or short durations [1-3]. For example, medical records (MRs) generally do not contain details of care outside of the point of service of the single health care provider, claims data contain few variables related to clinical outcomes, and registries often do not contain complete longitudinal data [4-7]. The integration of clinical data from different sources such as MRs [8], disease registries, or quality initiatives with large administrative claims repositories has been shown to increase the volume and quality of available data [9-12]. For example, integrated data allow the inclusion of important clinical factors when analyzing health care utilization and costs, as recorded in claims [13]. Such integrated observational data sets have also been used to generate predictive algorithms to better identify patients with cancer [14-17] and their disease characteristics [18-20].

Lung cancer is the second most common cancer in the United States, with approximately 230,000 new diagnoses in 2020 [21]. It is the leading cause of cancer-related deaths in the United States, projected at 136,000 in 2020 [22]. Non-small cell lung cancer (NSCLC) accounts for approximately $85 \%$ of all lung cancer cases [23]. Treatment modalities for advanced and/or metastatic NSCLC include radiotherapy, chemotherapy, targeted therapy, or a combination therapy [24]. Over the last few years, second-line (2L) treatment options have expanded rapidly with the introduction of immune checkpoint and epidermal growth factor receptor inhibitors and associated predictive biomarkers [25].

Treatment sequencing in the setting of NSCLC is not well characterized, largely because of the sparseness of applicable studies, which tend to be limited by inadequate data. This study was designed based on the rationale that a combination of retrospective data from multiple sources, such as MRs, administrative claims, and care quality initiatives, would provide a solid foundation for observing and characterizing real-world treatment outcomes at a lower cost than a traditional site-based prospective approach.

\section{Objectives}

The central objective of this study is to create an integrated database from several complementary sources and to assess the feasibility and effectiveness of these integrated observational data for health outcomes research. Patient characteristics and outcomes were described to evaluate the enrichment attained through integration. This analysis presents a descriptive summary of the final study cohort that was obtained for the study.

\section{Methods}

\section{Study Design}

RESOUNDS (Real-World Treatment Sequences and Outcomes Among Patients With Non-Small Cell Lung Cancer) was a retrospective, observational cohort study that integrated data from 4 sources: administrative claims from the HealthCore Integrated Research Database (HIRD), clinical data from a quality initiative called the Cancer Care Quality Program (CCQP), clinical data extracted from patients' MRs obtained from treating providers, and all-cause mortality data from the Death Master File of the US Social Security Administration. Details of the RESOUNDS study design and each of these data sources have been published previously [26]. The study protocol was approved by the New England Institutional Review Board before the commencement of data collection activities. This study was conducted in full compliance with the relevant provisions of the Health Insurance Portability and Accountability Act.

\section{Patient Identification}

Patients diagnosed with lung cancer who initiated 2L therapy between November 01, 2015, and April 13, 2018, were identified in the HIRD and CCQP data. Patients were required to receive 1 of the following $2 \mathrm{~L}$ therapies alone or in combination: atezolizumab, docetaxel, erlotinib, nivolumab, pembrolizumab, pemetrexed, or ramucirumab. This subset of the original set of therapies listed in the protocol [26] was selected based on treatment guidelines and observed frequency of use during the study period, to ensure sufficient sample sizes to evaluate treatment patterns. Patients aged under 18 years at the start of $2 \mathrm{~L}$ therapy were excluded. Due to the absence of specific International Classification of Diseases, Ninth and Tenth Revision, Clinical Modification codes for NSCLC, cancer type was confirmed via CCQP or MR data. Follow-up for all-cause death events was conducted through March 31, 2019.

\section{Integrated Database Development}

Patients were first identified in the CCQP data, where information on the type of lung cancer (NSCLC or not) was available, and information for patients with a record of $2 \mathrm{~L}$ therapies of interest was retained. All cancer stages were included in the analyses. Second, lung cancer diagnosis and treatment claims were used to identify patients with $2 \mathrm{~L}$ treatment in the HIRD. Patients who also had claims for other primary cancers were retained. All patients identified in the CCQP data were also included in the HIRD sample; patients who appeared in the HIRD but not the CCQP were retained. Third, copies of MRs were obtained from selected patients' $2 \mathrm{~L}$ prescribers (focusing on oncologists, as identified in the HIRD) and screened for qualification (presence of evidence for NSCLC and that the index treatment was used as therapy for NSCLC). Regulatory and operational requirements for inclusion in this process consisted of patients having a fully insured status (vs administrative services only) and presence of complete contact 
information for the $2 \mathrm{~L}$ prescriber. Once obtained and screened, clinical information was abstracted from each record by trained health information management technicians using a standardized form. The target sample size for MR abstraction was 398 patients, based on the expected feasible accrual over the 2.5-year patient identification period.

Data from each source were accumulated in 3 consecutive waves to continuously build the database. After each MR abstraction wave was complete, the claims and CCQP data were refreshed to the most current date at that point to obtain additional follow-up outcomes. The integrated data were used to establish the main analysis cohort, consisting of patients with both claims and either CCQP or MR data (or both). Eligible patients from the HIRD who did not appear in the CCQP and for whom no MRs were obtained were included in the claims-only cohort (these patients could have any type and stage of lung cancer).

\section{Patient Characteristics and Outcomes}

Demographic and clinical characteristics, treatment patterns, and survival outcomes were recorded. Baseline was defined as the 6 months before the index date (start of $2 \mathrm{~L}$ therapy). The Quan-Charlson Comorbidity Index (QCI) was calculated, excluding lung cancer and metastatic carcinoma [27]. A patient was considered to be on the same line of therapy until new agents were added (except for maintenance and platinum agent switching), a gap of $>90$ days between treatments, end of follow-up, or (for $2 \mathrm{~L}$ and higher) discontinuation. The percentage of patients flagged as deceased (for all causes) was calculated using a combination of the Death Master File, a hospitalization discharge code of deceased from claims, and mortality recorded from the health plan enrollment files.

\section{Statistical Analysis}

Univariate statistics including means, SDs, and medians for continuous variables and relative frequencies and percentages for categorical variables were reported. No hypothesis testing was performed. Statistical analysis was performed using SAS version 9.3 (SAS Institute Inc).

\section{Results}

\section{Data Integration and Patient Selection}

Following data integration, the main analysis cohort consisted of 2195 patients. All patients had claims data, 2106 patients had CCQP data, and 407 patients had MR data (Table 1).

Approximately 47.14\% (997/2115) of patients fulfilled regulatory and operational requirements for their MRs to be requested from their 2L-prescribing providers; for $54.5 \%$ (543/997) of those, the records were obtained. A large number of MRs were not obtained as outreach was stopped after the planned sample size $(n=398)$ was achieved; others could not be obtained because the provider did not have a record of the particular patient or because of inability to contact the provider. Among the obtained records, the most frequent reason for exclusion was the absence of confirmation of NSCLC (43/543, $7.9 \%$ of the obtained records). The claims-only cohort comprised 931 patients. Table 2 details what variables were obtained from which source. 
Table 1. Patient selection.

\begin{tabular}{|c|c|c|c|c|}
\hline Criteria & $\begin{array}{l}\text { First wave sam- } \\
\text { ple (patients, n) }\end{array}$ & $\begin{array}{l}\text { Second wave } \\
\text { sample }^{a} \text { (pa- } \\
\text { tients, } n \text { ) }\end{array}$ & $\begin{array}{l}\text { Third wave } \\
\text { sample (pa- } \\
\text { tients, n) }\end{array}$ & $\begin{array}{l}\text { Final sample } \\
\text { (patients, } n \text { ) }\end{array}$ \\
\hline \multicolumn{5}{|l|}{ Step A: Patients identified from $\mathrm{CCQP}^{\mathrm{c}}$} \\
\hline Step 1: Patients with non-small cell lung cancer & 295 & 760 & 1428 & $-{ }^{\mathrm{d}}$ \\
\hline Step 2: From step A1, patients with $2 L^{e}$ therapy $^{\mathrm{f}}$ & 174 & 469 & 863 & - \\
\hline \multicolumn{5}{|l|}{ Step B: Patients identified from claims } \\
\hline Step 1: Patients with lung cancer claim before start of first-line therapy & 640 & 1058 & 2187 & - \\
\hline Step 2: From step B1, patients with 2L therapy & 368 & 600 & 1127 & - \\
\hline \multicolumn{5}{|l|}{ Step C: Combined patients from CCQP and claims } \\
\hline Step 1: From A2 and B2, unique patients with $2 \mathrm{~L}$ therapy & 423 & 756 & 1732 & 2115 \\
\hline \multicolumn{5}{|l|}{ Step D: Patients considered for $\mathrm{MR}^{\mathrm{g}}$ review } \\
\hline Step 1: Patients used for MR outreach & 149 & 279 & 718 & 997 \\
\hline Step 2: Number of patient MRs obtained & 102 & 194 & 349 & 543 \\
\hline Step 3: Number of failed MRs ${ }^{\mathrm{h}}$ & 15 & 20 & 45 & 65 \\
\hline Step 4: Not used (target had been met previously) & - & - & 62 & 62 \\
\hline Step 5: Final MRs used & 87 & 174 & 242 & 416 \\
\hline $\begin{array}{l}\text { Step E: Main analysis cohort (patients with claims and either CCQP or } \\
\text { MR data) }\end{array}$ & 272 & 791 & 1446 & $2195^{\mathrm{i}}$ \\
\hline Step 1: Patients with CCQP data & 223 & 748 & 1399 & 2106 \\
\hline Step 2: Patients with MR data & 85 & 168 & 239 & 407 \\
\hline $\begin{array}{l}\text { Step F: Claims-only cohort (patients with claims data only, no CCQP or MR } \\
\text { data) }\end{array}$ & 377 & 243 & 659 & $931^{\mathrm{i}}$ \\
\hline
\end{tabular}

${ }^{\mathrm{a}}$ Second wave included all patients from the first wave.

${ }^{\mathrm{b}}$ The final sample removed duplicates that were included in $>1$ wave. For those patients, information from the most recent wave was used for analysis. ${ }^{\mathrm{c}} \mathrm{CCQP}$ : Cancer Care Quality Program.

${ }^{\mathrm{d}}$ Not available.

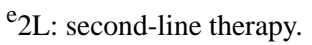

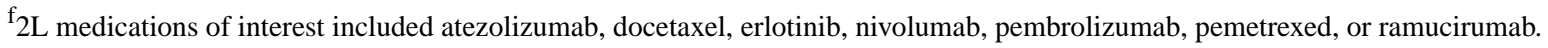
$\mathrm{g}_{\text {MR: medical record. }}$

${ }^{\mathrm{h}}$ Medical records excluded due to one or more of the following: no documentation of lung cancer, no documentation of non-small cell lung cancer, and patient mismatch (missing or unmatched name, sex, or date of birth; wrong timeframe; inconsistent clinical information).

${ }^{\mathrm{i}}$ These are the final sample sizes for the 2 cohorts of interest. 
Table 2. Variable sourcing by database type.

\begin{tabular}{|c|c|c|c|}
\hline Variable & $\begin{array}{l}\text { HealthCore Integrated Research Database } \\
\text { (claims) }\end{array}$ & $\begin{array}{l}\text { Cancer Care Quality } \\
\text { Program }\end{array}$ & Medical record \\
\hline Length of follow-up & $\boldsymbol{J}^{\mathrm{a}}$ & $-{ }^{b}$ & - \\
\hline Age & $\checkmark$ & - & $\checkmark$ \\
\hline Gender & $\checkmark$ & - & $\checkmark$ \\
\hline Health plan type & $\checkmark$ & - & - \\
\hline Geographic region of patient residence & $\checkmark$ & - & - \\
\hline Race/ethnicity & - & - & $\checkmark$ \\
\hline Weight, height, and BMI & - & - & $\checkmark$ \\
\hline Histology & - & $\checkmark$ & $\checkmark$ \\
\hline Staging & $\mathrm{Y}^{\mathrm{c}}$ & $\checkmark$ & $\checkmark$ \\
\hline Treating physician specialty & $\checkmark$ & - & - \\
\hline Smoking status & - & - & $\checkmark$ \\
\hline Performance status (Eastern Cooperative Oncology Group) & - & $\checkmark$ & $\checkmark$ \\
\hline Comorbidities & $\begin{array}{l}\checkmark \text { (Quan-Charlson Comorbidity Index, } \\
\text { secondary cancers) }\end{array}$ & - & - \\
\hline Mortality & $Z^{\mathrm{d}}$ & - & - \\
\hline
\end{tabular}

${ }^{\mathrm{a}}$ Indicates variable was sourced from the data set listed in the column header.

${ }^{b}$ Variable was not sourced from the data set listed in the column header.

${ }^{\mathrm{c}}$ Indicates the presence of claims for metastatic disease.

${ }^{\mathrm{d}}$ This was based on the Death Master File data from the US Social Security Administration.

\section{Demographic Characteristics at Baseline}

In the main analysis cohort, mean age was 62.1 (SD 9.27) years and $48.56 \%(1066 / 2195)$ were female (Table 3$)$, whereas in the claims-only cohort, mean age was 66.6 (SD 12.69) years and $52.1 \%$ (485/931) were female. More than two-thirds (1498/2195, $68.25 \%$ ) of the main analysis cohort were from the Midwest and South, and 23.01\% (505/2195) had Medicare Advantage or Supplemental and Part D coverage. In the claims-only cohort, patients were almost equally distributed across the West, Midwest, and South, with a smaller proportion $(164 / 931,17.6 \%)$ from the Northeast; almost half (457/931, 49.1\%) had Medicare Advantage coverage. Treating physician specialty based on claims listed oncologists for $67.52 \%(1482 / 2195)$ of the main analysis population and for $30.7 \%$ (286/931) of the claims-only sample; this difference is by design as only patients whose 2L-prescribing providers were listed as oncologists were included in the MR phase. Among the 407 patients with MR data, $45.7 \%$ (186/407) were White, 3.7\% (15/407) were Black, $3.2 \%$ (13/407) were other races, and 47.4\% (193/407) had no race information. Race was not available in patients without MRs. 
Table 3. Demographic characteristics at baseline (on or close to second-line therapy initiation date).

\begin{tabular}{|c|c|c|}
\hline Variables & Main analysis cohort $(\mathrm{n}=2195)$ & Claims-only cohort $(\mathrm{n}=931)$ \\
\hline Age at second-line therapy initiation (years), mean (SD) & $62.1(9.27)$ & $66.6(12.69)$ \\
\hline \multicolumn{3}{|l|}{ Age categories (years), n (\%) } \\
\hline $18-39$ & $22(1.0)$ & $33(3.5)$ \\
\hline $40-64$ & $1509(68.7)$ & $343(36.8)$ \\
\hline $65-74$ & $412(18.8)$ & 278 (29.9) \\
\hline$\geq 75$ & $252(11.5)$ & $277(29.8)$ \\
\hline Female, n (\%) & $1066(48.6)$ & $485(52.1)$ \\
\hline \multicolumn{3}{|l|}{ Health plan type, n (\%) } \\
\hline Health maintenance organization & $769(35.0)$ & $225(24.2)$ \\
\hline Preferred provider organization & $1126(51.3)$ & $628(67.5)$ \\
\hline Consumer-driven health plan & $300(13.7)$ & $78(8.4)$ \\
\hline Medicare Advantage ${ }^{\mathrm{a}}, \mathrm{n}(\%)$ & $505(23.0)$ & $457(49.1)$ \\
\hline Affordable Care Act exchange plan, n (\%) & $550(25.1)$ & $106(11.4)$ \\
\hline \multicolumn{3}{|l|}{ Geographic region of patient, $n(\%)$} \\
\hline Northeast & $344(15.7)$ & $164(17.6)$ \\
\hline Midwest & $815(37.1)$ & $262(28.1)$ \\
\hline South & $683(31.1)$ & $274(29.4)$ \\
\hline West & $353(16.1)$ & $231(24.8)$ \\
\hline \multicolumn{3}{|l|}{ Treating physician specialty, n (\%) } \\
\hline Oncology & $1482(67.5)$ & $286(30.7)$ \\
\hline Pulmonary medicine & $34(1.5)$ & $18(1.9)$ \\
\hline Primary care provider & $77(3.5)$ & $36(3.9)$ \\
\hline Other & $481(21.9)$ & $133(14.3)$ \\
\hline Missing & $121(5.5)$ & $458(49.2)$ \\
\hline
\end{tabular}

${ }^{\mathrm{a} I n c l u d e s ~ S u p p l e m e n t a l ~ a n d ~ P a r t ~ D ~ p l a n s . ~}$

\section{Clinical Characteristics at Baseline}

In the main analysis cohort, the mean QCI was 1.6 (SD 1.59). The most frequent comorbidities were dyspnea (1417/2195, $64.56 \%)$, chronic pulmonary disease $(1125 / 2195,51.25 \%)$, hypertension $(1073 / 2195,48.88 \%)$, anemia $(880 / 2195,40.09 \%)$, and dyslipidemia $(792 / 2195,36.08 \%$; Table 4$)$. More than half of the main analysis cohort $(1224 / 2195,55.76 \%)$ had claims for additional or secondary malignancies and $79.41 \%$ (1743/2195) had claims for metastatic disease. In the claims-only cohort, the mean QCI was 1.8 (SD 1.69). The most frequently occurring comorbidities were hypertension $(565 / 931,60.7 \%)$, dyspnea (542/931, 58.2\%), and dyslipidemia (403/931, 43.3\%). Almost three-quarters $(681 / 931,73.1 \%)$ had codes for other malignancies and $67.9 \%(632 / 931)$ had codes for metastatic disease.
In the main analysis cohort, additional clinical information was available via CCQP and/or MRs (Table 5). Among the 407 patients with MR data, 59.2\% (241/407) were former smokers, $16.5 \%$ (67/407) were current smokers, $14.3 \%$ (58/407) were never smokers, and $10.1 \%$ (41/407) had no documentation. Height and weight were available for the majority (341/407, $83.8 \%$ height; $371 / 407,91.2 \%$ weight) of patients; mean BMI was 26.1 (SD 6.36). The most common cancer histology was adenocarcinoma $(271 / 407,66.6 \%)$; for most of the remainder, histology was not documented. Metastasis was noted in MRs for $95.1 \%(387 / 407)$ of the patients, most commonly to the lymph nodes (289/407, 71.0\%). Eastern Cooperative Oncology Group (ECOG) performance status was available for $96.26 \%$ $(2113 / 2195)$ of the sample, and an ECOG score $\geq 2$ was observed in $21.20 \%(448 / 2113)$ of patients. 
Table 4. Clinical characteristics from claims at baseline (over 6 months before second-line therapy initiation date).

\begin{tabular}{|c|c|c|}
\hline Variables & Main analysis cohort $(\mathrm{n}=2195)$ & Claims-only cohort $(\mathrm{n}=931)$ \\
\hline $\mathrm{QCI}^{\mathrm{a}}$, mean $(\mathrm{SD})$ & $1.6(1.59)$ & $1.8(1.69)$ \\
\hline \multicolumn{3}{|l|}{ QCI categories, $n(\%)$} \\
\hline 0 & $570(26.0)$ & $230(24.7)$ \\
\hline 1 & $705(32.1)$ & $271(29.1)$ \\
\hline 2 & $414(18.9)$ & $185(19.9)$ \\
\hline $3-5$ & $444(20.2)$ & $212(22.8)$ \\
\hline $6+$ & $62(2.8)$ & $33(3.5)$ \\
\hline \multicolumn{3}{|l|}{ QCI comorbidities, $n(\%)$} \\
\hline Myocardial infarction & $112(5.1)$ & $46(4.9)$ \\
\hline Congestive heart failure & $195(8.9)$ & $111(11.9)$ \\
\hline Peripheral vascular disease & $357(16.3)$ & $186(20.0)$ \\
\hline Cerebrovascular disease & $255(11.6)$ & $100(10.7)$ \\
\hline Dementia & $18(0.8)$ & $10(1.1)$ \\
\hline Chronic pulmonary disease & $1125(51.2)$ & $390(41.9)$ \\
\hline Connective tissue/rheumatic disease & $57(2.6)$ & $32(3.4)$ \\
\hline Peptic ulcer disease & $31(1.4)$ & $13(1.4)$ \\
\hline Mild liver disease & $421(19.2)$ & $162(17.4)$ \\
\hline Moderate or severe liver disease & $10(0.5)$ & $<10^{\mathrm{b}}$ \\
\hline Paraplegia and hemiplegia & $50(2.3)$ & $<10^{\mathrm{b}}$ \\
\hline Renal disease & $172(7.8)$ & $127(13.6)$ \\
\hline Diabetes with chronic complications & $96(4.4)$ & $75(8.1)$ \\
\hline Diabetes without chronic complications & $380(17.3)$ & $211(22.7)$ \\
\hline Malignancy (excluding lung cancer) & $1224(55.8)$ & $681(73.1)$ \\
\hline Metastatic carcinoma & $1743(79.4)$ & $632(67.9)$ \\
\hline AIDS/HIV & $<10^{\mathrm{b}}$ & $<10^{\mathrm{b}}$ \\
\hline \multicolumn{3}{|l|}{ Other comorbidities of interest, $n(\%)$} \\
\hline Anemia (any) & $880(40.1)$ & $376(40.4)$ \\
\hline Anemia due to chemotherapy & $323(14.7)$ & $92(9.9)$ \\
\hline Asthma & $166(7.6)$ & $88(9.5)$ \\
\hline Cardiac dysrhythmias & $375(17.1)$ & $199(21.4)$ \\
\hline Coronary heart disease & $410(18.7)$ & $209(22.4)$ \\
\hline Depression & $338(15.4)$ & $139(14.9)$ \\
\hline Dyslipidemia & $792(36.1)$ & $402(43.2)$ \\
\hline Dyspnea & $1417(64.6)$ & $542(58.2)$ \\
\hline Hypertension & $1073(48.9)$ & $565(60.7)$ \\
\hline Idiopathic fibrosis of the lung & $15(0.7)$ & $<10^{\mathrm{b}}$ \\
\hline Interstitial lung disease & $29(1.3)$ & $<10^{\mathrm{b}}$ \\
\hline Peripheral vascular disease & $361(16.4)$ & $187(20.1)$ \\
\hline Pneumonia & $508(23.1)$ & $151(16.2)$ \\
\hline Pneumonitis & $29(1.3)$ & $16(1.7)$ \\
\hline Pulmonary fibrosis & $112(5.1)$ & $<10^{\mathrm{b}}$ \\
\hline
\end{tabular}




\begin{tabular}{lll}
\hline Variables & Main analysis cohort $(\mathrm{n}=2195)$ & Claims-only cohort $(\mathrm{n}=931)$ \\
\hline Stroke & $255(11.6)$ & $100(10.7)$ \\
Thyroid disease & $272(12.4)$ & $165(17.7)$ \\
Tuberculosis & $<10^{\mathrm{b}}$ & $<10^{\mathrm{b}}$ \\
\hline
\end{tabular}

${ }^{\mathrm{a} Q C I}$ : Quan-Charlson Comorbidity Index.

${ }^{\mathrm{b}}$ Values $<10$ have not been reported for patient confidentiality. 
Table 5. Clinical characteristics from Cancer Care Quality Program and/or medical records at baseline (on or close to second-line therapy initiation date).

\begin{tabular}{|c|c|}
\hline Variables & Main analysis cohort \\
\hline \multicolumn{2}{|l|}{ Information from $\mathrm{MRs}^{\mathrm{a}}$; valid $\mathrm{N}=\mathbf{4 0 7}$} \\
\hline \multicolumn{2}{|l|}{ Smoking status, n (\%) } \\
\hline Current smoker & $67(16.5)$ \\
\hline Former smoker & $241(59.2)$ \\
\hline Never smoker & $58(14.3)$ \\
\hline Not documented & $41(10.1)$ \\
\hline Presence of number of years smoked, $n(\%)$ & $201(49.4)$ \\
\hline Number of years smoked, mean (SD) & $36.1(13.48)$ \\
\hline Presence of weight, $n(\%)$ & $371(91.2)$ \\
\hline Weight (pounds), mean (SD) & $165.0(44.48)$ \\
\hline Presence of height, $n(\%)$ & $341(83.8)$ \\
\hline Height (inches), mean (SD) & $66.5(3.88)$ \\
\hline Presence of BMI, n (\%) & $339(83.3)$ \\
\hline BMI, mean (SD) & $26.1(6.36)$ \\
\hline \multicolumn{2}{|l|}{ Histology, n (\%) } \\
\hline Adenocarcinoma & $271(66.6)$ \\
\hline Large-cell carcinoma & $9(2.2)$ \\
\hline Bronchioloalveolar carcinoma & $2(0.5)$ \\
\hline Mixed & $3(0.7)$ \\
\hline Unspecified nonsquamous & $2(0.5)$ \\
\hline Other & $4(1.0)$ \\
\hline Unknown/not documented & $116(28.5)$ \\
\hline Presence of metastasis, $n(\%)$ & $387(95.1)$ \\
\hline Lymph nodes (thoracic region) & $289(71.0)$ \\
\hline Supraclavicular nodes & $87(21.4)$ \\
\hline Superior mediastinal nodes & $201(49.4)$ \\
\hline Aortic nodes & $64(15.7)$ \\
\hline Inferior mediastinal nodes & $132(32.4)$ \\
\hline Hilar, lobar, and/or (sub)segmental nodes & $199(48.9)$ \\
\hline Bone & $190(46.7)$ \\
\hline Other respiratory systems (not trachea) & $163(40.0)$ \\
\hline Brain & $121(29.7)$ \\
\hline Liver & $72(17.7)$ \\
\hline Adrenal gland & $59(14.5)$ \\
\hline Number of metastases sites, mean (SD) & $3.2(1.90)$ \\
\hline \multicolumn{2}{|l|}{ Information from Cancer Care Quality Program and/or MRs; valid N=2195 } \\
\hline Eastern Cooperative Oncology Group performance status, n (\%) & $2113(96.26)$ \\
\hline 0 & $464(21.96)$ \\
\hline 1 & $1201(56.84)$ \\
\hline 2 & $364(17.23)$ \\
\hline 3 & $74(3.50)$ \\
\hline
\end{tabular}




\begin{tabular}{cc}
\hline Variables & Main analysis cohort \\
\hline 4 & $10(0.47)$ \\
5 & $0(0)$ \\
TNM $^{\mathbf{b}}$ stage classification, $\mathbf{n}(\%)$ & $2146(97.77)$ \\
0 & $0(0)$ \\
1 & $<10$ \\
2 & $32(1.49)$ \\
3 & $167(7.78)$ \\
4 & $1935(90.17)$ \\
Unknown or not documented & $<10$
\end{tabular}

${ }^{\mathrm{a}} \mathrm{MR}$ : medical record.

${ }^{\mathrm{T}} \mathrm{TNM}$ : tumor/lymph nodes/metastasis cancer staging system.

\section{Length of Follow-Up and Mortality}

The mean length of follow-up in months was 7.9 (SD 5.77) for the main analysis cohort (median 6.8) and 9.1 (SD 6.06) for the claims-only cohort (median 8.6). Death (for all causes) was observed in $37.77 \%(829 / 2195)$ of the main analysis cohort and $29.3 \%(273 / 931)$ of the claims-only cohort.

\section{Treatment Patterns}

Among the 1974 patients with first-line (1L) treatment information, $69.50 \% \quad(1372 / 1974)$ used platinum-based regimens, $37.69 \%$ (744/1974) used pemetrexed-containing regimens, and $16.51 \% \quad(326 / 1974)$ used single-agent chemotherapy (treatment groups are not mutually exclusive; Table 6). The mean duration of $1 \mathrm{~L}$ therapy was 128 (median
90) days; $56.84 \%(1122 / 1974)$ switched to $2 \mathrm{~L}$ therapy with a gap $\leq 90$ days and $43.16 \%(852 / 1974)$ had a gap of $>90$ days before initiating $2 \mathrm{~L}$. The most frequent $2 \mathrm{~L}$ treatment was immunotherapy $(1094 / 2195,49.84 \%)$, followed by platinum-based regimens $(472 / 2195,21.50 \%)$. The mean duration of 2L therapy was 169 (median 121) days; this variable was right-censored due to loss of follow-up. For patients with third- and/or fourth-line therapy ( $\mathrm{n}=731$ and 265 , respectively), platinum-based regimens were used most frequently $(418 / 731$, $57.2 \%$ of third-line patients and $139 / 265,52.5 \%$ of fourth-line patients), and $21.6 \%$ (158/731) of third-line patients and $20.4 \%$ (54/265) of fourth-line patients also used immunotherapy. Among the 269 patients who received radiation therapy after the initial diagnosis of NSCLC, 46.1\% (124/269) patients received radiation therapy as a palliative treatment. 
Table 6. Treatment patterns from Cancer Care Quality Program and claims, measured from the initiation of first-line treatment to the end of follow-up.

\begin{tabular}{|c|c|}
\hline Therapy & $\begin{array}{l}\text { Main analysis cohort } \\
(\mathrm{N}=2195)\end{array}$ \\
\hline $1 L^{a}$ therapy, $n(\%)$ & $1974(89.9)$ \\
\hline \multicolumn{2}{|l|}{ Chemotherapy, n (\%) } \\
\hline Platinum-based regimen & $1372(69.5)$ \\
\hline Nonplatinum-based regimen & $90(4.6)$ \\
\hline Pemetrexed-containing regimen & $744(37.7)$ \\
\hline Single-agent chemotherapy & $326(16.5)$ \\
\hline \multicolumn{2}{|l|}{ Immunotherapy, $\mathbf{n}(\%)$} \\
\hline PD-1/PD-(L) $1^{\mathrm{b}}$ inhibitor-containing regimen & $241(12.2)$ \\
\hline \multicolumn{2}{|l|}{ Targeted therapy, n (\%) } \\
\hline EGFR $^{\mathrm{c}}$ TKIs $^{\mathrm{d}}$-containing regimen & $98(5.0)$ \\
\hline EGFR $\mathrm{mAb}{ }^{\mathrm{e}}$-containing regimen & $11(0.6)$ \\
\hline VEGF $^{\mathrm{f}} \mathrm{mAb}$-containing regimen & $308(15.6)$ \\
\hline $\mathrm{ALK}^{\mathrm{g}}$ inhibitor & $21(1.1)$ \\
\hline Duration of time (days) between initial lung cancer diagnosis and $1 \mathrm{~L}$ treatment, mean (SD) & $134.6(380.98)$ \\
\hline Duration (days) of $1 \mathrm{~L}$ therapy, mean $(\mathrm{SD})^{\mathrm{h}}$ & $127.7(142.75)$ \\
\hline \multicolumn{2}{|l|}{ Treatment change, $\mathbf{n}(\%)$} \\
\hline Gap of $\leq 90$ days before $2 \mathrm{~L}^{\mathrm{i}}$ & $1122(56.8)$ \\
\hline Gap of $>90$ days before $2 \mathrm{~L}$ & $852(43.2)$ \\
\hline 2L therapy, $n(\%)$ & $2195(100.0)$ \\
\hline \multicolumn{2}{|l|}{ Chemotherapy } \\
\hline Platinum-based regimen & $472(21.5)$ \\
\hline Nonplatinum-based regimen & $221(10.1)$ \\
\hline Pemetrexed-containing regimen & $344(15.7)$ \\
\hline Single-agent chemotherapy & $441(20.1)$ \\
\hline \multicolumn{2}{|l|}{ Immunotherapy } \\
\hline PD-1/PD-L1 inhibitor-containing regimen & $1094(49.8)$ \\
\hline \multicolumn{2}{|l|}{ Targeted therapy } \\
\hline EGFR TKIs-containing regimen & $36(1.6)$ \\
\hline EGFR mAb-containing regimen & $10(0.5)$ \\
\hline VEGF mAb-containing regimen & $141(6.4)$ \\
\hline ALK inhibitor & $<10^{\mathrm{j}}$ \\
\hline Duration (days) of $2 \mathrm{~L}$ therapy, mean $(\mathrm{SD})^{\mathrm{k}}$ & $168.6(148.4)$ \\
\hline Radiation therapy following initial diagnosis of non-small cell lung cancer, $n(\%)$ & $269(12.3)$ \\
\hline \multicolumn{2}{|l|}{ Intent of radiation therapy, $\mathrm{n}(\%)$} \\
\hline Curative & $21(7.8)$ \\
\hline Palliative & $124(46.1)$ \\
\hline Both curative and palliative (separate instances) & $15(5.6)$ \\
\hline Unknown & $109(40.5)$ \\
\hline
\end{tabular}

\footnotetext{
${ }^{\mathrm{a}} 1 \mathrm{~L}$ : first-line therapy.
} 
${ }^{\mathrm{b}} \mathrm{PD}-(\mathrm{L}) 1$ : programmed death-(ligand) 1.

${ }^{c}$ EGFR: epidermal growth factor receptor.

${ }^{\mathrm{d}}$ TKI: tyrosine kinase inhibitor.

e mAb: monoclonal antibodies.

${ }^{f}$ VEGF: vascular endothelial growth factor.

${ }^{\mathrm{g}} \mathrm{ALK}$ : anaplastic lymphoma kinase.

h Median 90.0.

${ }^{i}$ L: second-line therapy.

${ }^{\mathrm{j}}$ Values $<10$ have not been reported for patient confidentiality.

$\mathrm{k}$ Median 121.0.

\section{Discussion}

\section{Principal Findings}

This study combined 3 data sources for the analysis of real-world outcomes in patients with NSCLC, conducting data integration on a large scale across disparate but complementary sources. It was designed to simulate a prospective observational study by identifying patients upfront within large preexisting databases and then following them within the data set to examine outcomes. One of the potential strengths of this approach is the development of a database that includes demographic, clinical, and health care resource utilization data that can more accurately assess health outcomes.

The use of big data from multiple sources, such as health plan enrollment, disease registries, and scanned image repositories, among others, is becoming more important for the accurate determination of patient outcomes, particularly in the setting of NSCLC [28-31]. With the current availability of a wide range of newer, more effective systemic therapies, including several novel biologic agents, the use of diverse provider, institutional, and registry databases is increasingly necessary to evaluate outcomes due to the gaps in administrative claims data alone [32-35]. As treatments in oncology have improved, patients with lung cancer are living longer with the ability to personalize care with novel targeted therapies. This approach, coupled with more effective treatment, means that treatment strategies are increasingly complex, and factors influencing these strategies and their resultant outcomes are not fully identifiable in administrative claims data. As a result, the effective evaluation of treatment outcomes increasingly draws on data from multiple sources across lines of treatment, providers, and institutions.

Real-world evidence (RWE), which is largely derived from big health care data, has increasingly been driven by important technological advances, including machine learning, natural language processing improvements in electronic medical systems, and the ability to link clinical and health claims data in private and public systems [9]. As RWE grows and gains value, especially for pragmatic clinical trials (PCTs), the traditional gold standard of a randomized clinical trial (RCT) is facing major hurdles: low recruitment rates, small patient populations, long durations, and high costs. This evolving environment, along with growing interest in PCTs, is increasing the importance of big data and RWE as a complement to RCTs [36,37].

Furthermore, a bigger role for RWE is developing in decision making across the health care system, including regulators, payers, providers, and patients. Part of the reason is that although RCTs have internal validity, which is essential for safety and efficacy determinations, results from clinical studies may have limited external validity. At the same time, RWE studies using big data are able to explore key clinical questions that are outside the scope of RCTs. Such studies are well suited for investigations seeking safety and effectiveness outcomes data for broader target populations. This is especially valuable for the evaluation of fast-tracked medical products, which typically gain regulatory approval based on limited data. In addition, large RWE studies are invaluable in detecting the side effects of treatments over longer periods. Other circumstances in which RWE is valuable include exploration of rare diseases, assessing the impact of treatment adherence, when rapid retrospective results are needed, comparing multiple treatments that have not been explored in trials, and focusing on population subsets of interest, given more heterogeneity and larger population sizes in real-world data compared with clinical trials [36-38].

Due to the frequency of onset of NSCLC later in life, our study sample included patients with an average age greater than 60 years, with females constituting about half of the study population, which is consistent with other real-world US outcomes studies that examined patients with NSCLC [39-48]. All prior studies, to our knowledge, that focused on the United States used 1 or 2 of the following data sources: administrative claims, registry data, or MR. Limitations of these studies fall into 2 categories: (1) missing data on potential confounders and/or outcomes of interest (eg, claims data can assess utilization outcomes but lack disease characteristics; MR data have a rich set of clinical characteristics but lack longitudinality and utilization or cost data) and (2) limited generalizability (eg, the SEER-Medicare linked data in the United States capture claims and cancer registry data only for patients aged 65 years or older).

The ability of our study to integrate data across 3 sources to create a cohort of NSCLC patients with rich clinical and economic data offers an important addition to the comparatively small body of data on the performance of data integration methods and the determination of health outcomes based on these data for patients with NSCLC. To the extent that our study sample reflects the larger national population affected by lung cancer and with commercial insurance, these data could be instructive for a range of decisions made by multiple health care stakeholders including providers and patients requiring insights into the allocation of resources and overall disease management that cannot be completely ascertained from a single data source alone. One example would be the interaction of biomarker testing, treatment choice, and health outcomes. Integrated data 
sets such as RESOUNDS that can be refreshed regularly also offer many opportunities for future research, such as treatment sequencing, disease progression, and health care resource utilization and costs.

\section{Data Integration Challenges}

Our study also highlighted some challenges in the creation, maintenance, and analysis of large integrated data sets. Integration of data sets in the midst of a rapid shift in the treatment landscape (such as the introduction of immune checkpoint inhibitors for oncology) may impact the value of data sets that are large and deep, but that include periods of time that are no longer relevant to current standards of care. The maintenance of these data sets requires constant refresh and update, so that the periods of interest to the investigator can be current and available for analysis. The wealth of data available in MRs presents challenges in identifying the trade-offs between generating a limited set of relevant but reasonably quickly available data versus a broader set of data that is potentially available but more difficult to obtain and prepare for analysis. Methods of data integration and data extraction may be improved with machine learning or natural language processing to reduce the manual extraction via data collection forms that was used in this study. Patient sample sizes available for analysis diminish when multiple data sources are required. Finally, there were specific data integration challenges in our study that resulted in additional effort needed by the project team to understand and address (eg, the estimated 2L therapy start date for a given patient sometimes differed between the data sources, plan enrollment changes entailed patients leaving or entering the data set multiple times, and conflicts between data sources for a given variable had to be resolved).

\section{Study Limitations}

Results based on integrated data must also be viewed with some limitations. The data quality and content will depend on the underlying data selected for integration. Specific to the data used for this project, limitations include the following: CCQP data were collected at the time of the prior authorization request, not at diagnosis. CCQP offers incentives to physicians for treating according to evidence-based guidelines created by the health plan, which could have influenced treatment choices. MR data may be underreported or missing due to vague, incomplete, or illegible entries; the inability to locate the required information; or missing patient files. ECOG performance status, a standard data item in cancer trials, is not always assessed in real-world patient care settings (in our study, this variable was available for $96.26 \%(2113 / 2195)$ of the sample, mostly from the CCQP), and information on race/ethnicity is often missing in claims data. Similarly, tumor growth and progression information is collected in various formats and levels of detail outside of a clinical trial setting. As a result, some of our research questions of interest had underpopulated data. Efforts by payers to tie provider reimbursement to the collection of key data points, for example, through quality improvement initiatives, may over time alleviate some of the missing data issues. Data collected during MR abstraction may have measurement errors linked to inconsistent coding, transcription, and data transfer errors. The typical limitations of claims data also apply. For example, a diagnosis code on a medical claim (eg, for secondary malignancies) does not guarantee the presence of a disease. Similarly, a claim for a prescription fill does not indicate that the medication was consumed or taken as prescribed. The generalizability of claims-based results is confined to similarly insured populations (eg, commercial, US-based in this study).

\section{Conclusions}

The care of patients with NSCLC requires a range of resources in a variety of settings in the real world. NSCLC and other forms of cancer are increasingly being managed like chronic diseases with a broad range of increasingly effective treatments. The assessment of real-world data to evaluate outcomes among patients with NSCLC will require the integration of a broad range of clinical data with health plan claims data. Overcoming data integration and completeness challenges will allow better informed decision making by all stakeholders of the health care system.

\section{Acknowledgments}

Funding for the study was provided to HealthCore, Inc by Eli Lilly and Company. Bernard Tulsi, an employee of HealthCore, Inc at the time of the study, provided writing and editorial support for this manuscript.

\section{Conflicts of Interest}

MG is an employee of HealthCore, Inc, an independent research organization that received funding from Eli Lilly and Company for the conduct of this study. CM, KW, ZC, and LH are employees and stockholders of Eli Lilly and Company. GC was an employee of Eli Lilly and Company at the time the study was conducted. LW was an employee of HealthCore at the time the study was conducted.

\section{References}

1. Garrison LP, Neumann PJ, Erickson P, Marshall D, Mullins CD. Using real-world data for coverage and payment decisions: the ISPOR Real-World Data Task Force report. Value Health 2007;10(5):326-335 [FREE Full text] [doi: 10.1111/j.1524-4733.2007.00186.x] [Medline: 17888097]

2. Mahajan R. Real world data: additional source for making clinical decisions. Int J Appl Basic Med Res 2015;5(2):82 [FREE Full text] [doi: 10.4103/2229-516X.157148] [Medline: 26097811]

3. National Academies of Sciences, Engineering, and Medicine, Health and Medicine Division, Board on Health Sciences Policy, Forum on Drug Discovery, Development, and Translation. Examining the impact of real-world evidence on medical 
product development. Proceedings published by the National Academies of Sciences, Engineering, and Medicine chronicle the presentations and discussions at a workshop, symposium, or other event convened by the National Academies 2019. [doi: 10.17226/25352] [Medline: $\underline{30964617]}$

4. Brooks GA, Bergquist SL, Landrum MB, Rose S, Keating NL. Classifying Stage IV lung cancer from health care claims: a comparison of multiple analytic approaches. JCO Clin Cancer Inform 2019 May;3:1-19 [FREE Full text] [doi: 10.1200/CCI.18.00156] [Medline: 31070985]

5. Hess LM, Winfree KB, Muehlenbein CE, Zhu YE, Oton AB, Princic N, et al. Debunking myths while understanding limitations. Am J Public Health 2020 May;110(5):e2. [doi: 10.2105/AJPH.2020.305603] [Medline: 32267743]

6. Jairam V, Park HS. Strengths and limitations of large databases in lung cancer radiation oncology research. Transl Lung Cancer Res 2019 Sep;8(Suppl 2):172-183 [FREE Full text] [doi: 10.21037/tlcr.2019.05.06] [Medline: 31673522 ]

7. Takahashi Y, Nishida Y, Asai S. Utilization of health care databases for pharmacoepidemiology. Eur J Clin Pharmacol 2012 Feb;68(2):123-129. [doi: 10.1007/s00228-011-1088-2] [Medline: 21808989]

8. Berner ES, Detmer DE, Simborg D. Will the wave finally break? A brief view of the adoption of electronic medical records in the United States. J Am Med Inform Assoc 2005;12(1):3-7 [FREE Full text] [doi: 10.1197/jamia.M1664] [Medline: 15492029]

9. Agiro A, Chen X, Eshete B, Sutphen R, Clark BE, Burroughs CM, et al. Data linkages between patient-powered research networks and health plans: a foundation for collaborative research. J Am Med Inform Assoc 2019 Jul 01;26(7):594-602 [FREE Full text] [doi: 10.1093/jamia/ocz012] [Medline: 30938759]

10. Ma Q, Chung H, Shambhu S, Roe M, Cziraky M, Jones WS, et al. Administrative claims data to support pragmatic clinical trial outcome ascertainment on cardiovascular health. Clin Trials 2019 Aug;16(4):419-430. [doi: 10.1177/1740774519846853] [Medline: $\underline{\text { 31081367] }}$

11. Pine M, Jordan HS, Elixhauser A, Fry DE, Hoaglin DC, Jones B, et al. Enhancement of claims data to improve risk adjustment of hospital mortality. J Am Med Assoc 2007 Jan 03;297(1):71-76. [doi: 10.1001/jama.297.1.71] [Medline: 17200477]

12. Wilson J, Bock A. The benefit of using both claims data and electronic medical record data in health care analysis. Optum White Paper. 2012. URL: https://www.optum.com/content/dam/optum/resources/whitePapers/ Benefits-of-using-both-claims-and-EMR-data-in-HC-analysis-WhitePaper-ACS.pdf [accessed 2021-03-03]

13. Ke X, Navaratnam P, Sasane R, Lawrence DFE, Friedman HS, Tulsi BB, et al. Determinants of high cost in multiple sclerosis patients: a claims and chart review study. Curr Med Res Opin 2016 Sep;32(9):1589-1597. [doi: 10.1080/03007995.2016.1192529] [Medline: 27207562]

14. Beachler DC, de Luise C, Yin R, Gangemi K, Cochetti PT, Lanes S. Predictive model algorithms identifying early and advanced stage ER+/HER2- breast cancer in claims data. Pharmacoepidemiol Drug Saf 2019 Feb;28(2):171-178. [doi: 10.1002/pds.4681] [Medline: $\underline{30411431]}$

15. Bronson MR, Kapadia NS, Austin AM, Wang Q, Feskanich D, Bynum JPW, et al. Leveraging linkage of cohort studies with administrative claims data to identify individuals with cancer. Med Care 2018 Dec;56(12):83-89 [FREE Full text] [doi: 10.1097/MLR.0000000000000875] [Medline: 29334524]

16. Turner RM, Chen Y, Fernandes AW. Validation of a case-finding algorithm for identifying patients with Non-small Cell Lung Cancer (NSCLC) in administrative claims databases. Front Pharmacol 2017;8:883 [FREE Full text] [doi: 10.3389/fphar.2017.00883] [Medline: 29249970]

17. Parlett LE, Beachler DC, Lanes S, Hoover RN, Cook MB. Validation of an algorithm for claims-based incidence of prostate cancer. Epidemiology 2019 May;30(3):466-471 [FREE Full text] [doi: 10.1097/EDE.0000000000001007] [Medline: $\underline{30829831]}$

18. Clarke CL, Feigelson HS. Developing an algorithm to identify history of cancer using electronic medical records. EGEMS (Wash DC) 2016;4(1):1209 [FREE Full text] [doi: 10.13063/2327-9214.1209] [Medline: 27195308]

19. Sathiakumar N, Delzell E, Yun H, Jooste R, Godby K, Falkson C, et al. Accuracy of medicare claim-based algorithm to detect breast, prostate, or lung cancer bone metastases. Med Care 2017 Dec;55(12):144-149. [doi:

10.1097/MLR.0000000000000539] [Medline: 29135778]

20. Uno H, Ritzwoller DP, Cronin AM, Carroll NM, Hornbrook MC, Hassett MJ. Determining the time of cancer recurrence using claims or electronic medical record data. JCO Clin Cancer Inform 2018 Dec;2:1-10 [FREE Full text] [doi: 10.1200/CCI.17.00163] [Medline: $\underline{30652573}$ ]

21. Siegel RL, Miller KD, Jemal A. Cancer statistics, 2020. CA Cancer J Clin 2020 Jan;70(1):7-30 [FREE Full text] [doi: 10.3322/caac.21590] [Medline: 31912902]

22. American Cancer Society. URL: https://www.cancer.org/research/cancer-facts-statistics/all-cancer-facts-figures/ cancer-facts-figures-2020.html [accessed 2021-03-03]

23. Houston KA, Henley SJ, Li J, White MC, Richards TB. Patterns in lung cancer incidence rates and trends by histologic type in the United States, 2004-2009. Lung Cancer 2014 Oct;86(1):22-28 [FREE Full text] [doi: 10.1016/j.lungcan.2014.08.001] [Medline: 25172266] 
24. Kalemkerian GP, Loo BW, Akerley W, Attia A, Bassetti M, Boumber Y, et al. NCCN guidelines insights: small cell lung cancer, version 2.2018. J Natl Compr Canc Netw 2018 Oct;16(10):1171-1182. [doi: 10.6004/jnccn.2018.0079] [Medline: 30323087]

25. Morabito A. Second-line treatment for advanced NSCLC without actionable mutations: is immunotherapy the 'panacea' for all patients? BMC Med 2018 Feb 16;16(1):24 [FREE Full text] [doi: 10.1186/s12916-018-1011-0] [Medline: 29448944]

26. Hess LM, Kern DM, Carter GC, Winfree K, Wang L, Sontag A, et al. Real-world treatment sequences and outcomes among patients with non-small cell lung cancer (RESOUNDS) in the United States: study protocol. JMIR Res Protoc 2017 Oct 11;6(10):e195 [FREE Full text] [doi: 10.2196/resprot.7750] [Medline: 29021129]

27. Quan H, Li B, Couris CM, Fushimi K, Graham P, Hider P, et al. Updating and validating the Charlson comorbidity index and score for risk adjustment in hospital discharge abstracts using data from 6 countries. Am J Epidemiol 2011 Mar 15;173(6):676-682. [doi: 10.1093/aje/kwq433] [Medline: 21330339]

28. Asan O, Nattinger AB, Gurses AP, Tyszka JT, Yen TWF. Oncologists' views regarding the role of electronic health records in care coordination. JCO Clin Cancer Inform 2018 Dec;2:1-12 [FREE Full text] [doi: 10.1200/CCI.17.00118] [Medline: 30652555]

29. Cortinovis D, Abbate M, Bidoli P, Pelizzoni D, Canova S. Interpretation of lung cancer study outcomes. J Thorac Dis 2015 Nov;7(11):E541-E547 [FREE Full text] [doi: 10.3978/j.issn.2072-1439.2015.11.26] [Medline: 26716052]

30. Tevaarwerk AJ, Wisinski KB, Buhr KA, Njiaju UO, Tun M, Donohue S, et al. Leveraging electronic health record systems to create and provide electronic cancer survivorship care plans: a pilot study. J Oncol Pract 2014 May;10(3):e150-e159 [FREE Full text] [doi: 10.1200/JOP.2013.001115] [Medline: 24520142]

31. Wu J, Tan Y, Chen Z, Zhao M. Decision based on big data research for non-small cell lung cancer in medical artificial system in developing country. Comput Methods Programs Biomed 2018 Jun;159:87-101. [doi: 10.1016/j.cmpb.2018.03.004] [Medline: 29650322]

32. Borghaei H, Paz-Ares L, Horn L, Spigel DR, Steins M, Ready NE, et al. Nivolumab versus docetaxel in advanced nonsquamous non-small-cell lung cancer. N Engl J Med 2015 Oct 22;373(17):1627-1639 [FREE Full text] [doi: 10.1056/NEJMoa1507643] [Medline: 26412456]

33. Brahmer J, Reckamp KL, Baas P, Crinò L, Eberhardt WE, Poddubskaya E, et al. Nivolumab versus docetaxel in advanced squamous-cell non-small-cell lung cancer. N Engl J Med 2015 Jul 09;373(2):123-135. [doi: 10.1056/nejmoa1504627]

34. Garon EB, Ciuleanu T, Arrieta O, Prabhash K, Syrigos KN, Goksel T, et al. Ramucirumab plus docetaxel versus placebo plus docetaxel for second-line treatment of stage IV non-small-cell lung cancer after disease progression on platinum-based therapy (REVEL): a multicentre, double-blind, randomised phase 3 trial. Lancet 2014 Aug 23;384(9944):665-673. [doi: 10.1016/S0140-6736(14)60845-X] [Medline: 24933332]

35. Herbst RS, Baas P, Kim D, Felip E, Pérez-Gracia JL, Han J, et al. Pembrolizumab versus docetaxel for previously treated, PD-L1-positive, advanced non-small-cell lung cancer (KEYNOTE-010): a randomised controlled trial. Lancet 2016 Apr 09;387(10027):1540-1550. [doi: 10.1016/S0140-6736(15)01281-7] [Medline: 26712084]

36. Hampson G, Towse A, Dreitlein B, Henshall C, Pearson S. Real-world evidence for coverage decisions: opportunities and challenges. J Comp Eff Res 2018 Dec;7(12):1133-1143 [FREE Full text] [doi: 10.2217/cer-2018-0066] [Medline: 30411972]

37. Katkade VB, Sanders KN, Zou KH. Real world data: an opportunity to supplement existing evidence for the use of long-established medicines in health care decision making. J Multidiscip Healthc 2018;11:295-304 [FREE Full text] [doi: 10.2147/JMDH.S160029] [Medline: 29997436]

38. Berger M, Daniel G, Frank K, Hernandez A, McClellan M, Okun S, et al. A framework for regulatory use of real-world evidence. Duke Margolis Center for Health Policy. 2017 Sep 13. URL: https://healthpolicy.duke.edu/sites/default/files/ 2020-08/rwe white paper 2017.09.06.pdf [accessed 2021-03-03]

39. Abernethy AP, Arunachalam A, Burke T, McKay C, Cao X, Sorg R, et al. Real-world first-line treatment and overall survival in non-small cell lung cancer without known EGFR mutations or ALK rearrangements in US community oncology setting. PLoS One 2017;12(6) [FREE Full text] [doi: 10.1371/journal.pone.0178420] [Medline: 28644837]

40. Bittoni MA, Arunachalam A, Li H, Camacho R, He J, Zhong Y, et al. Real-world treatment patterns, overall survival, and occurrence and costs of adverse events associated with first-line therapies for medicare patients 65 years and older with advanced non-small-cell lung cancer: a retrospective study. Clin Lung Cancer 2018 Sep;19(5):629-645 [FREE Full text] [doi: 10.1016/j.cllc.2018.04.017] [Medline: 29885945]

41. Davies J, Patel M, Gridelli C, de Marinis F, Waterkamp D, McCusker ME. Real-world treatment patterns for patients receiving second-line and third-line treatment for advanced non-small cell lung cancer: a systematic review of recently published studies. PLoS One 2017;12(4) [FREE Full text] [doi: 10.1371/journal.pone.0175679] [Medline: 28410405]

42. Foster CC, Sher DJ, Rusthoven CG, Verma V, Spiotto MT, Weichselbaum RR, et al. Overall survival according to immunotherapy and radiation treatment for metastatic non-small-cell lung cancer: a National Cancer Database analysis. Radiat Oncol 2019 Jan 28;14(1):18 [FREE Full text] [doi: 10.1186/s13014-019-1222-3] [Medline: 30691492]

43. Hess LM, Louder A, Winfree K, Zhu YE, Oton AB, Nair R. Factors associated with adherence to and treatment duration of erlotinib among patients with non-small cell lung cancer. J Manag Care Spec Pharm 2017 Jun;23(6):643-652. [doi: 10.18553/jmcp.2017.16389] [Medline: 28530522] 
44. Horn L, Bauml J, Forde PM, Davis KL, Myall NJ, Sasane M, et al. Real-world treatment patterns and survival of patients with BRAF V600-mutated metastatic non-small cell lung cancer. Lung Cancer 2019 Feb;128:74-90. [doi: 10.1016/j.lungcan.2018.12.003] [Medline: 30642457]

45. Li Y, Appius A, Pattipaka T, Feyereislova A, Cassidy A, Ganti AK. Real-world management of patients with epidermal growth factor receptor (EGFR) mutation-positive non-small-cell lung cancer in the USA. PLoS One 2019;14(1) [FREE Full text] [doi: 10.1371/journal.pone.0209709] [Medline: 30608948]

46. Nadler E, Espirito JL, Pavilack M, Boyd M, Vergara-Silva A, Fernandes A. Treatment patterns and clinical outcomes among metastatic non-small-cell lung cancer patients treated in the community practice setting. Clin Lung Cancer 2018 Jul;19(4):360-370 [FREE Full text] [doi: 10.1016/j.cllc.2018.02.002] [Medline: 29576407]

47. Ryan KJ, Skinner KE, Fernandes AW, Punekar RS, Pavilack M, Walker MS, et al. Real-world treatment patterns among patients with unresected stage III non-small-cell lung cancer. Future Oncol 2019 Sep;15(25):2943-2953 [FREE Full text] [doi: 10.2217/fon-2018-0939] [Medline: 31037966]

48. Simeone JC, Nordstrom BL, Patel K, Klein AB. Treatment patterns and overall survival in metastatic non-small-cell lung cancer in a real-world, US setting. Future Oncol 2019 Oct;15(30):3491-3502 [FREE Full text] [doi: 10.2217/fon-2019-0348] [Medline: 31497994]

\author{
Abbreviations \\ 1L: first-line \\ 2L: second-line \\ CCQP: Cancer Care Quality Program \\ ECOG: Eastern Cooperative Oncology Group \\ HIRD: HealthCore Integrated Research Database \\ MR: medical record \\ NSCLC: non-small cell lung cancer \\ QCI: Quan-Charlson Comorbidity Index \\ RCT: randomized clinical trial \\ RESOUNDS: Real-World Treatment Sequences and Outcomes Among Patients With Non-Small Cell Lung \\ Cancer \\ RWE: real-world evidence
}

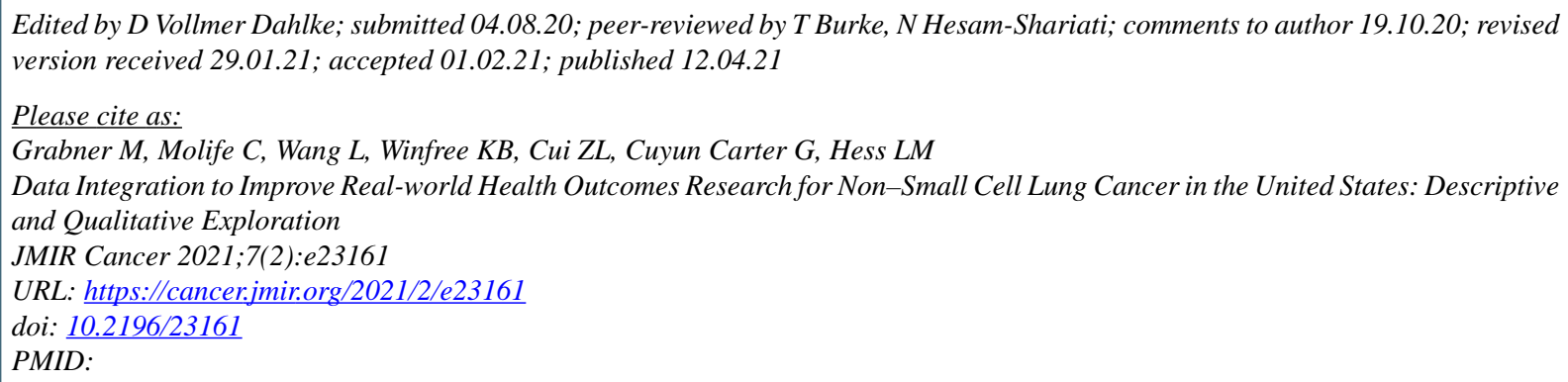

CMichael Grabner, Cliff Molife, Liya Wang, Katherine B Winfree, Zhanglin Lin Cui, Gebra Cuyun Carter, Lisa M Hess. Originally published in JMIR Cancer (http://cancer.jmir.org), 12.04.2021. This is an open-access article distributed under the terms of the Creative Commons Attribution License (https://creativecommons.org/licenses/by/4.0/), which permits unrestricted use, distribution, and reproduction in any medium, provided the original work, first published in JMIR Cancer, is properly cited. The complete bibliographic information, a link to the original publication on http://cancer.jmir.org/, as well as this copyright and license information must be included. 